University of Nebraska - Lincoln

DigitalCommons@University of Nebraska - Lincoln

USDA National Wildlife Research Center - Staff Publications
U.S. Department of Agriculture: Animal and Plant Health Inspection Service

2013

\title{
Comparisons between blackbird damage to corn and sunflower in North Dakota
}

\author{
Megan E. Klosterman \\ North Dakota State University
}

George M. Linz

USDA/APHIS/WS National Wildlife Research Center, george.m.linz@aphis.usda.gov

Anthony Slowik

USDA/WS/NWRC

H. Jeffrey Homan

USDA/APHIS/Wildlife Services' National Wildlife Research, jeffrey.h.homan@aphis.usda.gov

Follow this and additional works at: https://digitalcommons.unl.edu/icwdm_usdanwrc

Klosterman, Megan E.; Linz, George M.; Slowik, Anthony; and Homan, H. Jeffrey, "Comparisons between blackbird damage to corn and sunflower in North Dakota" (2013). USDA National Wildlife Research Center - Staff Publications. 1232.

https://digitalcommons.unl.edu/icwdm_usdanwrc/1232

This Article is brought to you for free and open access by the U.S. Department of Agriculture: Animal and Plant Health Inspection Service at DigitalCommons@University of Nebraska - Lincoln. It has been accepted for inclusion in USDA National Wildlife Research Center - Staff Publications by an authorized administrator of DigitalCommons@University of Nebraska - Lincoln. 


\title{
Comparisons between blackbird damage to corn and sunflower in North Dakota
}

\author{
Megan E. Klosterman ${ }^{\mathrm{a}, 1}$, George M. Linz ${ }^{\mathrm{b}}$, Anthony A. Slowik ${ }^{\mathrm{b}, 2}$, H. Jeffrey Homan ${ }^{\mathrm{b}, *}$ \\ ${ }^{a}$ Department of Biological Sciences, North Dakota State University, Fargo, ND 58108, USA \\ ${ }^{\mathrm{b}}$ U.S. Department of Agriculture, Animal Plant Health Inspection Service, Wildlife Services, National Wildlife Research Center, 2110 Miriam Circle, Suite B, \\ Bismarck, ND 58501, USA
}

\section{A R T I C L E I N F O}

\section{Article history:}

Received 22 March 2013

Received in revised form 5 June 2013

Accepted 6 June 2013

\section{Keywords:}

Blackbirds

Corn

Prairie Pothole Region

North Dakota

Sunflower

\begin{abstract}
A B S T R A C T
For sunflower producers in North Dakota, blackbird (Icterinae) damage is a chronic problem costing millions of dollars annually. Sunflower damage surveys were last completed in the state in 1979-1980. Since the last surveys, corn plantings have increased 6-fold to $1500 \times 10^{3}$ ha, whereas sunflower hectarage has declined by $>75 \%$ to $310 \times 10^{3}$ ha. Blackbirds forage on both crops, and this rapid change in North Dakota's agricultural landscape was a sound inducement for reassessing crop damage. Field surveys are an important step in damage methods development because they are used for measuring efficacy, as well as assessing historical changes in the quality and quantity of damage. During 2009-2010, we conducted damage surveys on corn and sunflower. We surveyed 120 randomly selected $3.2 \times 3.2-\mathrm{km}$ plots in North Dakota's Prairie Pothole Region. This region of numerous wetlands has historically produced the majority of the state's sunflower crop, in addition to harboring a blackbird population of 25 million birds. Over the 2-year study, we measured damage in 68 cornfields and 27 sunflower fields. Annual damage averaged $5.0 \times 10^{3} \mathrm{t}\left(12 \mathrm{~kg} / \mathrm{ha}\right.$, US $\$ 1.3$ million) for corn and $7.2 \times 10^{3} \mathrm{t}$ (45 kg/ha, US $\$ 3.5$ million) for sunflower. Percentage damage was significantly greater in sunflower $(\bar{x}=2.7 \%)$ than corn $(\bar{x}=0.2 \%)$. The lower per-unit cost of producing corn makes it a potential lure crop for managing blackbird damage to sunflower. However, the two crops should be phenologically synchronized because corn matures earlier than sunflower and becomes less attractive to blackbirds.
\end{abstract}

Published by Elsevier Ltd.

\section{Introduction}

North Dakota annually leads North America in oilseed sunflower production, but plantings in North Dakota have fallen over $75 \%$, from $1300 \times 10^{3}$ ha in the late 1970 s to $310 \times 10^{3}$ ha today (NASS, 2013). The decline in sunflower has been precipitous in the Prairie Pothole Region (PPR), especially in the central and southern portions, which are renowned for their abundance of cattaildominated (Typha spp.) wetlands and concomitant large populations of blackbirds (Icterinae) (Nelms et al., 1999; Ralston et al., 2007). Sunflower damage caused by blackbirds generally ranks third (behind plant spacing and disease) as the most limiting factor on production (Kandel, 2013). Despite the likelihood of suffering greater overall economic losses from other sources (e.g., disease

\footnotetext{
* Corresponding author. Tel.: +1 701250 4469; fax: +1 7012504408 .

E-mail address: jeffrey.h.homan@aphis.usda.gov (H.J. Homan).

1 Present address: U.S. Department of Agriculture, California Wildlife Services, USA California State Office, 3419A Arden Way, Sacramento, CA 95825, USA.

2 Present address: U.S. Department of Agriculture, Plant Protection and Quarantine, 3509 Miriam Avenue, Suite A, Bismarck, ND 58501, USA.
}

and insects), producer surveys have indicated consistently that blackbirds are one of the leading causes of sunflower's decline in the PPR (Kleingartner, 2002; Klosterman, 2011; Kandel, 2013). This outsized influence on producer perceptions in part results from the lack of management techniques to significantly reduce damage, which effectively makes blackbirds an unmanageable problem and differentiates it from other potential sources of damage (Kleingartner, 2002; Linz et al., 2011).

Of the three major blackbird species in North Dakota, redwinged blackbirds (Agelaius phoeniceus $\mathrm{L}$ ) cause the most damage (Linz and Hanzel, 1997; Peer et al., 2003). According to North American Breeding Bird Survey indices, the PPR of North Dakota has some of the highest densities of red-winged blackbirds (RWBL) on the continent (Sauer et al., 2013). Peer et al. (2003) used the indices to estimate that 8.4 million RWBL were reproducing in North Dakota's PPR. By late summer, recruitment of young brings the population to 12.2 million birds. When combined with the two other resident populations of blackbirds, common grackles (Quiscalus quiscula L) and yellow-headed blackbirds (Xanthocephalus xanthocephalus Bonaparte), the late-summer population in the PPR is 25.4 million (from Peer et al., 2003). Most blackbird damage 


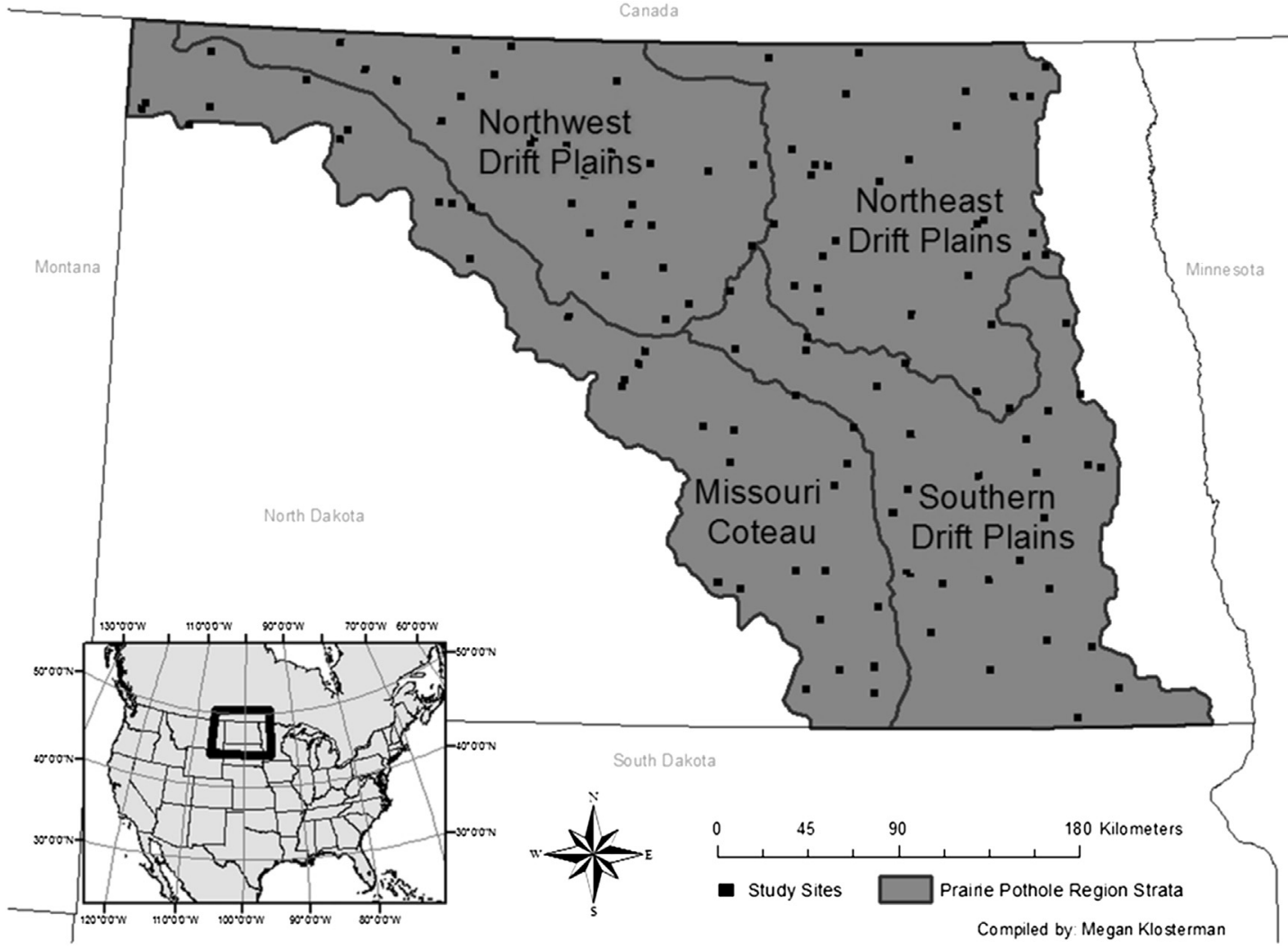

Fig. 1. The strata of the Prairie Pothole Region of North Dakota with locations of 120 sites used for bird damage surveys.

( $\sim 75 \%)$ occurs between late August and mid-September (Cummings et al., 1989). Blackbirds in North Dakota molt in late August, which hampers their flight ability, causing them to remain in natal areas (Linz et al., 1983). The majority of sunflower damage is thus attributed to resident birds (Dolbeer, 1982).

The last statewide bird damage surveys for sunflower in North Dakota were completed in 1979 and 1980 (Hothem et al., 1988). Although described nominally as 'statewide' surveys, they were largely conducted in the PPR ( $87 \%$ of the fields), where soil conditions are conducive for producing high yields of sunflower. Annual damage was $0.9 \%\left(18.3 \times 10^{3} \mathrm{t} @ 13 \mathrm{~kg} / \mathrm{ha}\right)$ and $2.6 \%\left(26.9 \times 10^{3} \mathrm{t} @\right.$ $30 \mathrm{~kg} / \mathrm{ha})$, respectively, which is equivalent to US $\$ 9.0$ million and $\$ 13.2$ million at oilseed sunflower's current price $(\$ 0.49 / \mathrm{kg}$, [March 2013]). Agricultural practices have changed since these data were gathered. For example, corn comprised only a small portion $\left(260 \times 10^{3} \mathrm{ha}\right)$ of agricultural plantings during the late 1970 s and early 1980s. Corn became an economically important crop in North Dakota in the early 2000s, and over the last decade has tripled to $1500 \times 10^{3}$ ha (NASS, 2013). Production increases were a result of higher prices and concurrent introduction of hybrid corn varieties better suited for the semi-arid climate and short-growing seasons of the northern Great Plains.

Corn producers have reported instances of blackbird damage, but no formal surveys have been conducted to document losses. Most of the corn damage occurs in early August during the milk stage and dough stage of kernel development, when kernels are soft (Weatherhead et al., 1982). Blackbirds usually switch to alternate food sources after the kernels harden (Linz et al., 1984). Sunflower damage occurs over a longer period than corn damage, starting about mid-August and lasting until the fields are harvested in October. The increase in corn production and the decrease in sunflower production in North Dakota has created an interesting dynamic in blackbird damage because corn and sunflower are both highly preferred foods (Linz et al., 1984). To our knowledge, no studies have measured damage in an agricultural landscape where two crops preferred by blackbirds are so easily accessible. Additionally, more than three decades have passed since the last sunflower damage surveys were conducted in North Dakota. The rapid change in crop compositions justified the need for new surveys. Damage surveys are important part of management research because they are used for evaluating potential efficacy of newly developed methods, as well as evaluating techniques in current use. Further, they can be used for measuring quantitative and qualitative changes of damage over time. From 2009 to 2010, we measured blackbird damage in mature sunflower and cornfields in 120 randomly selected $3.2 \times 3.2-\mathrm{km}$ plots in the PPR.

\section{Methods}

\subsection{Study area}

Our study area $\left(95,200 \mathrm{~km}^{2}\right)$ was in the Drift Prairie and Missouri Coteau physiographic regions (Fig. 1). These regions comprised just over one-half of North Dakota's land area. The topography of the PPR consisted of gently rolling ground moraines interspersed by flat extents of lake plains created from the Wisconsin Glaciation. The soils were glacial lake plain and glacial till plain, being highly permeable sandy loams and loamy sands. Originally an expansive region of nearly treeless mixed-grass prairie, most of the area has now been converted to cropland, with about $60 \%$ of the land in harvestable crops. Moderately extensive tracts of native prairie still exist, but they are often heavily grazed. Small shallow-basined wetlands (potholes) pocked the region. Wetland density averaged $7 / \mathrm{km}^{2}$ and area totaled 
Table 1

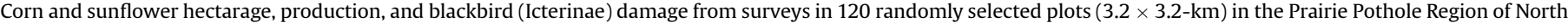
Dakota.

\begin{tabular}{|c|c|c|c|c|c|c|c|c|}
\hline \multirow[t]{2}{*}{ Category } & \multicolumn{4}{|l|}{ Corn } & \multicolumn{4}{|c|}{ Sunflower } \\
\hline & 2009 & 2010 & $\bar{x}$ & SE & 2009 & 2010 & $\bar{x}$ & SE \\
\hline Planted $\left(10^{3}\right.$ ha $)$ & 437 & 399 & 418 & 19.5 & 182 & 144 & 163 & 18.7 \\
\hline Production ( $10^{6}$ tonnes) & 3.2 & 3.3 & 3.2 & 0.07 & 0.3 & 0.2 & 0.3 & 0.04 \\
\hline \multicolumn{9}{|l|}{ Damage } \\
\hline Fields ( $n)$ & 30 & 38 & & & 15 & 12 & & \\
\hline$\%$ & 0.2 & 0.1 & 0.2 & 0.02 & 2.2 & 3.3 & $2.7^{\mathrm{a}}$ & 0.56 \\
\hline Tonnes $\left(10^{3}\right)$ & 6 & 4 & 5 & 0.7 & 7 & 8 & 7 & 0.5 \\
\hline $\mathrm{Kg} / \mathrm{ha}$ & 13 & 11 & 12 & 1.1 & 37 & 54 & 45 & 8.4 \\
\hline \$US/ha & 3.50 & 2.92 & 3.21 & 0.29 & 18.05 & 26.24 & 22.14 & 4.10 \\
\hline \$US total $\left(10^{6}\right)$ & 1.5 & 1.2 & 1.3 & 0.2 & 3.3 & 3.8 & 3.5 & 0.3 \\
\hline
\end{tabular}

${ }^{a}$ Damage for fields pooled over years greater in sunflower than corn $(P<0.001)$.

$13 \times 10^{3} \mathrm{~km}^{2}$ (Ralston et al., 2007). Hybrid cattail (Typha glauca) was a common emergent in many of the larger wetlands. Semipermanent wetlands, which harbor the largest number of blackbirds, contained $54 \%$ of the $2 \times 10^{3} \mathrm{~km}^{2}$ of cattail in the PPR (Ralston et al., 2007). Single arrays and multiple linear arrays of trees (shelterbelts) were planted throughout the region to reduce soil erosion. Lengthy unpredictable periods of above normal and below normal precipitation cause cyclic filling and drying of wetlands. The climate was mid-continental characterized by cold winters and warm summers. Temperatures ranged from -42 to $+45^{\circ} \mathrm{C}$, with a long term 30-yr average temperature of $5{ }^{\circ} \mathrm{C}$. Average annual total precipitation was $49.5 \mathrm{~cm}$, with 75\% occurring between April and September. Based on biogeography, the Drift Prairie was portioned into the following strata: Northeast Drift Plains (NEDP), Northwest Drift Plains (NWDP), and Southern Drift Plains (SODP) (Stewart and Kantrud, 1971).

\subsection{Damage estimates}

We estimated bird damage after the crops had reached full physiological maturity in late September. We used 120 randomly selected $3.2 \times 3.2-\mathrm{km}$ plots proportionally allocated among the Missouri Coteau (MICO) and the three biogeographical strata (Ralston et al., 2007). We sampled all corn and sunflower fields occurring in a $1.6-\mathrm{km}^{2}$ area located in the center of each $3.2 \times 3.2$ $\mathrm{km}$ plot. We divided each sampled field into an equal number of rows. One row was randomly selected from each half. For each row, the first sample plot of 5 consecutive plants was a randomly selected distance between $0 \mathrm{~m}$ (i.e., field edge) and $135 \mathrm{~m}$. Thereafter, our sample plots of 5 consecutive plants were located every $135 \mathrm{~m}$ until the end of the field. Generally, a minimum of 6 plots were sampled per row because fields were typically planted in 804$m$ lengths or multiples of that. If an uncultivated area existed in the row, we paced through it maintaining the 135 -m sampling distance. Plots falling on uncultivated areas were recorded as 'no plants' with pacing reset to zero. Unsampled plots were not replaced.

For sunflower, to determine the area available for damage, we averaged 2 perpendicular tape measurements of the damaged head and undeveloped center (light-colored, immature achenes). Sunflower damage was estimated using a $5-\mathrm{cm}^{2}$ gridded template (Dolbeer, 1975). Undamaged heads were left unmeasured and $0 \mathrm{~cm}^{2}$ was recorded. The percent damage on each head was calculated by dividing the area of bird damage (i.e., missing achenes) by the area of achenes potentially available for damage (i.e., minus undeveloped area) and multiplying by 100 . We calculated percent loss for each sunflower field by averaging the percent loss of all heads in all sampled plots. Corn damage was estimated by measuring the length and circumference of damaged ears along with length and width of the damaged area. Percent damage was estimated by dividing the damaged area by the product of ear length and circumference and multiplying by 100 . Percent loss was calculated similarly to sunflower. Percent loss was calculated for each crop by physiographic strata and all strata pooled.

We used GIS and USDA Cropland Data Layer digital maps to estimate corn and sunflower coverage in the PPR. We used the database of the National Agricultural Statistics Service for estimates of crops harvested, production, and pricing (NASS, 2013). Economic damage was reported using March 2013 commodity prices in US dollars (corn $\$ 0.27 / \mathrm{kg}$, sunflower $\$ 0.49 / \mathrm{kg}$ ).

\subsection{Statistical analysis}

We used arithmetic means and standard errors to describe central tendency and accuracy of the damage estimates. We used Wilcoxon-Mann-Whitney tests to assess statistical differences in damage within crop type between years and between crop types for years pooled. Statistical significance was accepted at $\alpha<0.10$.

\section{Results}

Blackbird damage to corn and sunflower averaged $5.0 \times 10^{3} \mathrm{t}$ $\left(12 \mathrm{~kg} / \mathrm{ha}\right.$ ) and $7.2 \times 10^{3} \mathrm{t}(45 \mathrm{~kg} / \mathrm{ha})$, respectively (Table 1$)$. Production losses were $\$ 1.3$ million for corn and $\$ 3.5$ million for sunflower. For fields pooled over years, percent damage was nearly $14 \times$ greater in sunflower $(\bar{x}=2.7 \%)$ than corn $(\bar{x}=0.2 \%)$. None of the 68 cornfields surpassed $10 \%$ damage and $3(4 \%)$ were between $1 \%$ and $2 \%$. Of the 27 sunflower fields, 3 (11\%) were > $10 \%$ damage, 8 (30\%) were between $1 \%$ and $10 \%$, and 16 (59\%) were $<1 \%$. In total, 4 fields had damage $>5 \%$, which is often considered a significant level of damage. The greatest damage per field for corn (1.5\%) occurred in 2009 in the MICO and for sunflower (20\%) in 2009 in the SODP. For corn, damage was greater in $2009(\bar{x}=0.2 \%, 13 \mathrm{~kg} / \mathrm{ha})$; whereas sunflower damage was greater in $2010(\bar{x}=3.3 \%, 54 \mathrm{~kg} / \mathrm{ha}$ ) (Table 1$)$. No difference was detected between years for damage estimates of $\operatorname{corn}\left(U_{30,38}=674.5, P=0.20\right)$ or sunflower $\left(U_{15,12}=99.0, P=0.68\right)$. With years pooled, bird damage was significantly less for corn than sunflower $\left(U_{68,27}=1489.0\right.$; $P<0.001)$.

Corn was planted in the PPR at $2.5 \times$ the coverage of sunflower (Table 1). Agricultural producers kept a consistent planting pattern between 2009 and 2010 with 82\% of the cornfields $(n=56)$ occurring in the SODP and $63 \%$ of the sunflower fields $(n=17)$ in the NWDP. For fields pooled over years, corn damage was lowest in the $\operatorname{SODP}(\bar{x}=0.1 \%, \mathrm{SE}=0.04, n=56)$ and highest in MICO $(\bar{x}=0.4 \%, \mathrm{SE}=0.36, n=4)$; sunflower damage was lowest in the NWDP $(\bar{x}=0.7 \%, \mathrm{SE}=0.21, n=17)$ and highest in the SODP $(\bar{x}=8.8 \%, \mathrm{SE}=5.80, n=3)$. About $57 \%$ and $46 \%$ of North Dakota's total corn and sunflower plantings, respectively, occurred within the PPR. 


\section{Discussion}

Regional surveys of blackbird damage in field crops in central and northern areas of the U.S. rarely exceed $2 \%$. For example, average corn damage was $0.6 \%$ over 8 annual statewide surveys in the Midwest (Dolbeer, 1981). Four surveys conducted in North Dakota in the 1970s and early 1980s showed that sunflower damage averaged 1.5\% (Henne et al., 1979; 1979 [unpublished report]; Hothem et al., 1988). Including our regional surveys, which had comparatively higher damage for sunflower and lower damage for corn, none approached the $5 \%$ threshold level of damage, which is a level at which some methods of damage abatement can become economically justified (Dolbeer, 1981; Linz and Homan, 2011; Linz et al., 2011). However, blackbird damage has a non-uniform distribution in the PPR, and regional estimates cannot adequately portray the magnitude of the effects on sunflower agriculture and agricultural practices. During the damage period, blackbirds are forming large pre-migratory assemblages in cattail-dominated wetlands. Densities can exceed 3000 birds/ha (Leitch et al., 1997). The activity areas of pre-migratory blackbirds are about $300 \mathrm{~km}^{2}$ and are focused on wetlands (Besser et al., 1979). Flocking behavior combined with limited ranges of activity leads to an inverse relationship between the distance from wetlands and severity of bird damage, which in turn causes damage to be spatially clumped (Besser et al., 1979; Dolbeer, 1981; Otis and Kilburn, 1988). Although regional estimates can provide a broad overview of the scope of damage, they tend to understate the impact of clumped damage. We speculate that clumping of sunflower damage has had a pervasive effect, leading to regionalized abandonment of sunflower.

The effect is particularly noticeable in the central and southern areas of the PPR, where cattail-dominated wetlands are in abundance (Ralston et al., 2007). Bird pressure on the crop ultimately causes some producers to drop sunflower from their rotations. The localized decline in crop availability causes increased damage rates $(\mathrm{kg} / \mathrm{ha})$ for neighboring producers because sunflower is preferred and sought after by blackbirds. This cyclically leads to even more producers abandoning the crop over an ever widening area until the crop begins to disappear from the region. Our damage surveys in the SODP, where corn dominates in coverage over sunflower by $16: 1$, seem to support the hypothesis of bird damage contributing toward regional declines of sunflower. The SODP, which in the early 1980s held the greatest number of sunflower plantings, now has the lowest hectarage of sunflower among the 4 strata, the highest average percent sunflower damage (9\%), and the highest damage per field (20\%).

Low regional crop coverage associated with high regional damage demonstrates the general relationship between absolute damage - relative damage, wherein absolute damage in a landscape or region is practically invariable (based upon feeding and energy requirements of the at-large population) and relative damage is strongly and inversely dependent on a crop's areal coverage (Leitch et al., 1997). For example, the strata in our study that had the highest plantings by crop type (Corn - SODP, Sunflower - NWDP) were also the same strata where respective damage was lowest. In the PPR, sunflower was planted at $40 \%$ the coverage of corn, and it was not unexpected that sunflower damage would be greater than corn. First, the foraging impact measured in $\mathrm{kg} / \mathrm{ha}$ was amplified by the smaller coverage of sunflower. Perhaps more importantly, sunflower with its higher energy content and longer period of susceptibility to depredation led to greater levels of damage than would be expected based solely on areal coverages of the two crops alone.

Comparable region-wide sunflower damage surveys have been conducted three other times in North Dakota (1978-1980). During $1978-1980,87 \%$ of the sunflower was planted in the 37 counties comprising the PPR (NASS, 2013). Thus, we believe that valid comparisons can be made between our surveys and these earlier ones. Compared to previous surveys, our study demonstrates that not only do more fields have $>10 \%$ damage, but that damage rates (as measured by $\mathrm{kg} / \mathrm{ha}$ ) have climbed. The surveys by Hothem et al. (1988) showed that fields in the damage category of $>10 \%$ were rare; for example, in 1979 they comprised $<2 \%$ of the samples. In our study, $11 \%$ of the fields had $>10 \%$ damage. Even more indicative is the change in damage rates over the 30 -year period since the last surveys. Hothem et al. (1988) reported damage rates in the PPR of $13 \mathrm{~kg} / \mathrm{ha}\left(1300 \times 10^{3}\right.$ ha planted in PPR counties) and $30 \mathrm{~kg} / \mathrm{ha}$ $\left(830 \times 10^{3} \mathrm{ha}\right)$ in 1979 and 1980, respectively, whereas (Henne et al., 1979; Henne et al., 1979 [unpublished report]) reported a damage rate of $18 \mathrm{~kg} / \mathrm{ha}\left(560 \times 10^{3} \mathrm{ha}\right)$ in 1978 . Our damage rates were $37 \mathrm{~kg} / \mathrm{ha}\left(180 \times 10^{3} \mathrm{ha}\right)$ and $54 \mathrm{~kg} / \mathrm{ha}\left(140 \times 10^{3} \mathrm{ha}\right)$ in 2009 and 2010, respectively. Indeed, the difference in damage rates between our study and the 1978-1980 studies may be even greater, because according to Hothem et al. (1988), the $30 \mathrm{~kg} / \mathrm{ha}$ rate included anomalous data from Stutsman County. Perusal of these data indicate a damage rate of $256 \mathrm{~kg} / \mathrm{ha}$, yielding a countywide loss of $17 \times 10^{3}$ t. This estimate represented $95 \%$ of the sunflower damage that was tallied in North Dakota in 1979 and 65\% of the damage in 1980. To put this amount of damage in further perspective using a bioenergetics analysis developed by Peer et al. (2003) for blackbirds in the northern Great Plains, Stutsman County alone in 1980 would conceivably have had to host the entire blackbird population ( $\sim 75$ million) in the northern Great Plains (including Canada) for the full 42-day damage period.

\section{Conclusions and management implications}

None of the ten counties that were leaders in sunflower production in North Dakota in 1980 was in the list of top ten counties in 2010. The geographical center of the top ten counties in 2010 (60 km NE of Bismarck) was located $170 \mathrm{~km}$ west of the geographical center of the top ten counties in 1980 (120 km NW of Fargo). The 1980 geographical center was located in the central portion of SODP, whereas the 2010 center was on western edge of the MICO. In South Dakota, a similar westward movement of production also occurred over the same period. South Dakota is second behind North Dakota in sunflower production, and it also has extensive PPR coverage in the eastern third of the state. South Dakota had only one county from the 1980 list of top ten sunflower producing counties that was on the 2010 list. The geographical center of production of the 2010 top ten counties had shifted westward $160 \mathrm{~km}$ from the 1980 geographical center. The 1980 center had moved from the Drift Plains physiographic region in the northeastern part of the state to the western edge of the Missouri Coteau.

However, unlike North Dakota, the decline in sunflower plantings in South Dakota stopped in 2003, stabilizing at approximately $200 \times 10^{3}$ ha. The stabilization in plantings suggests that the continued declines in North Dakota may not be related to competition from regional or world markets. Moreover, recent surveys of sunflower diseases (primarily, downy mildew and sclerotinia) do not indicate any physiographical differences in severity of disease outbreaks (Kandel, 2013). We hypothesize that market economics and disease are not related to the westward movement of production and that it is instead being driven by a retreat from the physiographic regions having high densities of semi-permanent wetlands and accompanying large populations of blackbirds.

We acknowledge that there are other factors besides blackbird damage causing the decline of sunflower in the PPR. Certainly, corn-based ethanol initiatives have had an effect and the development of glyphosate-resistant soybean has also led to large increases in plantings of this crop. However, sunflower was already in 
decline in North Dakota by the mid-1980s, long before these relatively new agricultural developments occurred. Intuitively, it does not seem that an organism that causes damage only ranging from $2 \%$ to $3 \%$ should have such an effect as to cause a crop's original center of production to move nearly $200 \mathrm{~km}$. However, in comparison to other sources of damage and loss, blackbird damage appears to have both economic and psychological components. Not only is it a form of unmanageable damage that occurs after crop inputs have reached their maximum, but the source of damage is easily visible to the producer and it occurs near harvest, when anticipation of success is highest. We argue that these factors working in concert will discourage sunflower producers over time and cause a regional abandonment of the crop, as has occurred in North Dakota and South Dakota.

To our knowledge, our damage surveys were the first that compared blackbird damage between two highly preferred crops. Our results indicated that blackbirds foraged heavily in both crops. Because of large differences in field production and unit pricing, corn could possibly serve as a lure crop, particularly if planted between sunflower and habitats heavily used by blackbirds. The plantings would need to be synchronized to match differences in phenology between the two crops because corn loses its attractiveness to blackbirds as the kernels harden. Lastly, lure crops are more effective when harassment techniques (e.g., propane cannons, pyrotechnics) are used to deter foraging in fields intended for protection (Linz et al., 2011).

\section{Acknowledgments}

We thank W. Bleier and G. Clambey for reviewing an earlier draft of this manuscript. We also thank M. Biondini and C. Doetkott for statistical guidance. J. Schanandore, D. Stonefish, J. Monson, and M. Strassburg assisted with data collection. Funding was provided by the U.S. Department of Agriculture, Wildlife Services, National Wildlife Research Center (NWRC) and the Department of Biological Sciences, North Dakota State University (NDSU). The research was conducted under the auspices of NWRC Study Protocol QA-1565. G. Linz served as study director. Safety guidelines were reviewed and approved by the NWRC and NDSU.

\section{References}

Besser, J.F., Berg, W.J., Knittle, C.E., 1979. Late-summer feeding patterns of red-winged blackbirds in a sunflower-growing area of North Dakota. Bird Control Semin. 8, 209-214. http://digitalcommons.unl.edu/icwdmbirdcontrol/ (accessed 13.03.13.).
Cummings, J.L., Guarino, J.L., Knittle, C.E., 1989. Chronology of blackbird damage to sunflowers. Wildl. Soc. Bull. 17, 50-52.

Dolbeer, R.A., 1975. A comparison of two methods for estimating bird damage to sunflowers. J. Wildl. Manag. 39, 802-806.

Dolbeer, R.A., 1981. Cost-benefit determination of blackbird damage control for cornfields. Wildl. Soc. Bull. 91, 44-51.

Dolbeer, R.A., 1982. Migration patterns for age and sex classes of blackbirds and starlings. J. Field Ornithol. 53, 28-46.

Henne, D.R., Pfeifer, W.K., Besser, J.F., 1979. Bird damage to sunflower in North Dakota in 1978. In: Sunflower Res. Workshop, Fargo, North Dakota, vol. 3 , pp. 16-17. http://www.sunflowernsa.com/research/searchable-database-offorum-papers/ (accessed 22.03.13.).

Hothem, R.L., DeHaven, R.W., Fairaizl, S.D., 1988. Bird Damage to Sunflower in North Dakota, South Dakota and Minnesota, 1979-1981. U.S. Fish Wildl. Serv. Tech. Rep. 15.

Kandel, H., 2013. Sunflower Crop Survey Report. North Dakota State Univer. Ag. Ext. Serv. http://www.ag.ndsu.edu/cpr/plant-science/sunflower-crop-surveyreport-05-29-13.

Kleingartner, L., 2002. Sunflower losses to blackbirds: an economic burden. In: Linz, G.M. (Ed.), Proceedings of a Special Symposium of the Wildlife Society 9th Annual Conference, 24-28 September 2002, Bismarck, North Dakota, USA, pp. 13-14.

Klosterman, M.E., 2011. Assessment of Blackbird Damage to Sunflower and Corn Fields in the Prairie Pothole Region of North Dakota. M.S. thesis. North Dakota State University, Fargo, USA.

Leitch, J.A., Linz, G.M., Baltezore, J.F., 1997. Economics of cattail (Typha spp.) control to reduce blackbird damage to sunflower. Agr. Ecosyst. Environ. 65, $141-149$.

Linz, G.M., Bolin, S.B., Cassel, J.F., 1983. Postnuptial and postjuvenal molts of redwinged blackbirds in Cass County, North Dakota. Auk 100, 206-209.

Linz, G.M., Hanzel, J.J., 1997. Birds and Sunflower. In: Sunflower Technology and Production, Agron. Monogr, vol. 35, pp. 381-394.

Linz, G.M., Homan, H.J., 2011. Use of glyphosate for managing invasive cattail (Typha spp.) to disperse blackbird (Icteridae) roosts. Crop Prot. 30, 98-104.

Linz, G.M., Homan, H.J., Werner, S.W., Hagy, H.M., Bleier, W.J., 2011. Assessment of bird management strategies to protect sunflower. BioScience 61, 960-970.

Linz, G.M., Vakoch, D.L., Cassel, J.F., Carlson, R.B., 1984. Food of red-winged blackbirds, Agelaius phoeniceus, in sunflower fields and corn fields. Can. Field-Nat. 98, 38-44.

National Agricultural Statistics Service [NASS], 2013. Quick Stats. http://quickstats. nass.usda.gov/ (accessed 22.03.13.).

Nelms, C.O., Otis, D.L., Linz, G.M., Bleier, W.J., 1999. Cluster sampling to estimate blackbird populations in North Dakota. Wildl. Soc. Bull. 27, 931-937.

Otis, D.L., Kilburn, C.M., 1988. Influence of Environmental Factors on Blackbird Damage to Sunflower. U.S. Fish Wildl. Serv. Tech. Rep. 16

Peer, B.D., Homan, H.J., Linz, G.M., Bleier, W.J., 2003. Impact of blackbird damage to sunflower: bioenergetic and economic models. Ecol. Appl. 13, 248-256.

Ralston, S.T., Linz, G.M., Bleier, W.J., Homan, H.J., 2007. Cattail distribution and abundance in North Dakota. J. Aquatic Plant Manage 45, 21-24.

Sauer, J.R., Hines, J.E., Fallon, J.E., Pardieck, K.L., Ziolkowski Jr., D.J., Link, W.A., 2013. The North American Breeding Bird Survey, Results and Analysis 1966-2011. Version 12.13.2011. USGS. Patuxent Wildlife Research Center, Laurel, MD. http:// www.mbr-pwrc.usgs.gov/bbs/ (accessed 22.03.13.).

Stewart, R.E., Kantrud, H.A., 1971. Classification of Natural Ponds and Lakes in the Glaciated Prairie Region. In: Bureau of Sport Fisheries and Wildlife, vol. 92. U.S. Fish and Wildlife Service Resource Publication.

Weatherhead, P.J., Tinker, S., Greenwood, H., 1982. Indirect assessment of avian damage to agriculture. J. Appl. Ecol. 19, 773-782. 